\title{
Research on the Impact of Green Credit on Profitability of Commercial Banks in China
}

\author{
Huang Danye $\mathrm{e}^{1, \mathrm{a}}$ \\ ${ }^{1}$ The college of Economics and Business administration, Nanjing University of Science and Technology, Nanjing, China
}

\begin{abstract}
This paper reviews the literature on green credit, and has a further understanding of the basic concepts of green credit and profitability of commercial banks, as well as the development status of green credit in China in recent years. Based on empirical data analysis, supplemented by theoretical analysis, this paper makes an empirical analysis of the impact of green credit on the profitability of China's commercial banks. Finally, according to the results of the empirical analysis, the corresponding opinions and suggestions are given.
\end{abstract}

\section{Introduction}

A brand-new credit policy "Opinions on Implementing Environmental Protection Policies and Regulations to Guard against Credit Risks" means that green credit has become an economic means. According to this economic measure, most banks have introduced a green credit mechanism to provide more and more support for energy-saving projects. If commercial banks can vigorously implement the green credit policy at this stage, it will provide strong support to China's environment-friendly enterprises, realize financial support to low-carbon and low-pollution industries, promote the transformation and development of enterprises, and further promote the realization of sustainable development goals. With the transformation of China's economic development to a green development trend, enterprises and society have many potential demand for green credit, which makes the impact of green credit on commercial banks' profitability more and more obvious. The implementation of green credit is not only an important way for commercial banks to fulfill their social responsibilities, but also a theoretical basis and way for them to enhance their international competitiveness, acquire green reputation and realize sustainable development.

\section{Literature Review and Theoretical Analysis}

Foreign literature mainly examines the impact of green credit on commercial banks through the Equator Principle [1]. Scholtens and Dam[2] believe that the operating costs of banks that join the Equator Principle increase and operating profits decrease. Mathuva and
Kiweu[3] found that kenya savings institutions with more social and environmental responsibilities have a lower rate of return on assets. Some scholars also believe that there are regional differences in the impact of green credit on banks. Finger et al [4] took 78 equatorial banks in the world from 2003 to 2015 as samples and found that in developed countries, interest income and return on net assets of commercial banks increased after adopting the equatorial principle. In developing countries, the opposite is true.

The scope and angle of domestic research on green credit are wide. First of all, Party Chunfang [5] believes that green credit has become an important trend in the development of modern finance. Wang Xianju [6] believes that an in-depth study of the policy environment and difficulties for commercial banks to implement green credit is of great significance to the development of banks. However, in the green credit practice of commercial banks, Liu Chuanyan [7] believes that there are a series of problems in China's commercial banks, such as imperfect credit policies, lack of supervision and incomplete information disclosure. Secondly, the development of green credit can be promoted through green credit risk management. Hu Naiwu and CaoDaWei [8] believe that commercial banks should closely combine the development of green credit with their own environmental risk management, and use quantitative management of environmental risks to promote the further development of green credit. Finally, the research on the relationship between green credit and bank performance is also different. Chen Haire [9] believes that the implementation of green credit can help improve the profitability of commercial banks. Shen Xiaohui [10] through empirical analysis shows that the implementation of green credit by commercial banks is not only conducive to the sustainable development of society and economy, but also conducive to their own

a743079472@qq.com 
development. Wang Ye et al [11] analyzed that green credit has significant side effects on the return on total assets of commercial banks. In addition, green credit has an impact on the performance of commercial banks. Li $\mathrm{Yu}$ [12] and others believe that the upgrading of the industrial structure of green credit has a positive promoting effect.

\section{Overview of Green Credit Development}

In recent years, the development of green credit has been extremely fast. Take Industrial and Commercial Bank of China as an example. As shown in Figure 1, the green credit scale of Industrial and Commercial Bank of China increased year by year from 2014 to 2018 . By the end of 2017, the total balance of all kinds of green financing was nearly 9 trillion yuan, of which green credit accounted for more than $95 \%$, becoming the main force to promote the construction of ecological civilization and the transformation of green development.

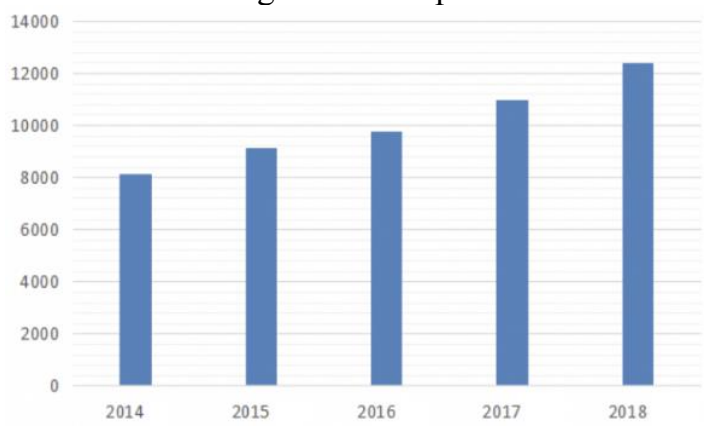

TABLE I. SET VARIABLES

\begin{tabular}{|l|l|l|}
\hline \multirow{4}{*}{ Interpreted } & Variable & Definition \\
\hline \multirow{5}{*}{ variable } & Return on Assets(ROA) & Net profit /average total assets \\
\cline { 2 - 3 } variable & Green Credit Ratio(GLR) & $\begin{array}{l}\text { Water Resources, Environment and Public } \\
\text { Facilities Management Loan Project Loan/Total } \\
\text { Bank Year-end Credit }\end{array}$ \\
\cline { 2 - 3 } & Asset-liability ratio(ZF) & Average total liabilities / average total assets \\
\cline { 2 - 3 } & Capital adequacy ratio(CAR) & $\begin{array}{l}\text { Capital adequacy ratio of banks at the end of the } \\
\text { year }\end{array}$ \\
\cline { 2 - 3 } & loan-to-deposit ratio(LDR) & Total loans / Total deposit \\
\cline { 2 - 3 } & rate of economic development (CS) & Annual economic growth rate \\
\cline { 2 - 3 } & $\begin{array}{l}\text { Intermediate Income } \\
\text { Proportion(ZJSR) }\end{array}$ & Intermediate business income / Total revenue \\
\cline { 2 - 3 } & non-performing loan ratio(NPLR) & Bad loan / Total loans \\
\hline
\end{tabular}

- Data source

This paper selects ten banks as sample banks: Industrial and Commercial Bank of China, China Construction Bank, Bank of China, Agricultural Bank of China, Bank of Communications, CITIC Bank, Industrial Bank, Ping An Bank, China Minsheng Bank and China Merchants Bank. These 10 banks can represent the development of China's overall banks.
Figure 1. Green Credit Scale of Industrial and Commerc ial Bank of China from 2014 to 2018 (Unit: RMB 100 m illion).

Source: ICBC Social Responsibility Report 2014 -2018

With the further promotion of the concept of environmental protection, the number of loans received by "two high and one surplus" enterprises has decreased, but it is still limited by the commercial nature of China's commercial banks in pursuing profits. Traditional environmental polluting enterprises need a large amount of loans due to the demand of development, which has stimulated the improvement of profit margins of commercial banks and limited the increase of green credit business.

Therefore, the development of green credit in our country still needs continuous adjustment and improvement.

\section{An Empirical Study on the Impact of Green Credit on Profitability of Commercial Banks in China}

\subsection{Indicator Selection and Data Source}

- Indicator selection

In this paper, the variables are set as shown in Table 1 by referring to previous literatures and papers. 2007, and then in the next year's statements, green credit was only used by some commercial banks, and from 2009 onwards, green credit was officially promoted. Therefore, this article starts from 2009 until the latest annual report is published. 


\subsection{Research Assumptions and Model Setting}

- Research hypothesis

Hypothesis 1: The larger the proportion of green credit, the higher the return on total assets of listed commercial banks.

Hypothesis 2: The smaller the non-performing loan ratio of listed commercial banks, the higher the return on total assets of listed banks.

$$
R \hat{O} A=\alpha+\beta_{1} G L R+\beta_{2} Z F+\beta_{3} C A R+\beta_{4} C S+\beta_{5} L D R+\beta_{6} Z J S R+\beta_{7} N P L R+\varepsilon
$$

Among them, ROA stands for return on total assets.

In this paper, we choose to do fixed effect model regression on relevant data. By comparing the significance level of the random effect model and the
- Model Setting

In view of the above assumptions, correlation regression analysis is made on the collected data.

By referring to other papers, the model is set as follows:

TABLE II. Individual Time Fixed EfFect Model

\begin{tabular}{|c|c|c|c|c|}
\hline \multicolumn{5}{|c|}{$\begin{array}{l}\text { Dependent Variable: ROA } \\
\text { Method: Pooled Least Squares } \\
\text { Sample: } 20092018 \\
\text { Included observations: } 100 \\
\text { Cross-sections included: } 10 \\
\text { Total pool (unbalanced) observations: } 100\end{array}$} \\
\hline Variable & Coefficient & Std. Error & t-Statistic & Prob. \\
\hline $\begin{array}{l}\text { C } \\
\text { GLR } \\
\text { ZF } \\
\text { CAR } \\
\text { CS } \\
\text { LDR } \\
\text { ZJSR } \\
\text { NPLR }\end{array}$ & $\begin{array}{l}-3.954134 \\
2.497810 \\
1.415385 \\
0.951214 \\
3.345653 \\
1.945601 \\
0.031934 \\
-0.247858\end{array}$ & $\begin{array}{l}0.241841 \\
1.134545 \\
0.111801 \\
0.014132 \\
3.11 \mathrm{E}-06 \\
0.159398 \\
0.215203 \\
0.219410\end{array}$ & $\begin{array}{l}-27.50270 \\
4.972714 \\
29.92508 \\
1.896567 \\
7.785874 \\
2.840567 \\
5.230137 \\
-1.609302\end{array}$ & $\begin{array}{l}0.0000 \\
0.0002 \\
0.0015 \\
0.6039 \\
0.0010 \\
0.0107 \\
0.0004 \\
0.5845\end{array}$ \\
\hline $\begin{array}{l}\text { R-squared } \\
\text { Adjusted R-squared } \\
\text { S.E. of regression } \\
\text { Sum squared resid } \\
\text { Log likelihood } \\
\text { F-statistic } \\
\text { Prob(F-statistic) }\end{array}$ & $\begin{array}{l}0.850784 \\
0.845392 \\
817.5631 \\
32083648 \\
-405.2428 \\
1446.039 \\
0.000000\end{array}$ & $\begin{array}{l}\text { Mean dep } \\
\text { S.D. depe } \\
\text { Akaike in } \\
\text { Schwarz } \\
\text { Hannan-C } \\
\text { Durbin-W }\end{array}$ & $\begin{array}{l}\text { lent var } \\
\text { nt var } \\
\text { riterion } \\
\text { rion } \\
\text { in criter. } \\
\text { on stat }\end{array}$ & $\begin{array}{l}10102.18 \\
1220.698 \\
11.28971 \\
7.06619 \\
16.31884 \\
2.112378\end{array}$ \\
\hline
\end{tabular}

The following equation is obtained:

$$
\begin{aligned}
& \hat{R O A}=-3.95+2.50 G L R+1.42 Z F+0.95 C A R+3.35 C S+1.95 L D R+0.03 Z J S R-0.25 N P L R \\
& (-27.5)(4.97) \quad(29.92) \quad(1.89) \quad ?(7.79) \quad(2.84) \quad(5.23) \quad(0-1.61) \\
& R^{2}=0.85 \quad \bar{R}^{2}=0.845 \quad D W=2.11 \quad F=1446.039
\end{aligned}
$$

\section{$F=1446.039$}

- Measurement test and regression results

Through analysis, the goodness-of-fit value of the model variables in this paper is 0.85 , which shows that the fitting degree of the equation is relatively high and $85 \%$ of return on total assets can be explained by explanatory variables and control variables.

(1) Green Credit Ratio (GLR). Green credit ratio refers to the total amount of loans for water conservancy, environmental and public facilities management projects/bank loans at the end of the year, which reflects the amount of green credit of banks. According to the

regression model, the coefficient is 2.50 , which indicates that each additional unit will lead to an increase of 2.50 units in ROA, showing a significant positive correlation.

(2) Capital adequacy ratio (CAR). Capital adequacy ratio is an index to measure the ability of commercial banks to avoid risks. The regression results of this paper show that its coefficient is 0.95 , indicating that it has a positive correlation with commercial banks' profitability, but its $P$ value is 0.6039 , which fails the significance test of variables, indicating that it cannot directly explain commercial banks' profitability. 
(3) NPLR. The higher the non-performing loan rate, the worse the profitability of the bank. This model also confirms this rule. The NPLR coefficient in the model is -0.247858 . However, in this model, the $\mathrm{P}$ value is 0.5845 , which does not pass the significance test of variables.

(4) loan-to-deposit ratio (LDR). The model shows that the loan-to-deposit ratio coefficient is 1.945601, showing a positive correlation. The $\mathrm{T}$ test value is 2.840567. Looking up the table shows that it has passed the significance test under the confidence level of $10 \%$, which indicates that loan-to-deposit ratio is an obvious factor affecting the profitability of commercial banks in this model.

(5) Asset-liability ratio (ZF). Asset-liability ratio shows the ratio of assets to liabilities, reflecting the longterm solvency of the bank. The model shows that the coefficient of asset-liability ratio is 1.415385 . That is, for every percentage point increase in the asset-liability ratio, commercial bank return on total assets will increase by $1.42 \%$.

(6) Intermediate Income Proportion (ZJSR). Generally speaking, the higher the ratio of intermediate income, the better the bank's ability to operate, and thus the higher the bank's ROA. In this paper, the coefficient of the proportion of middle income is positive, and the significance test is also passed. Therefore, the model in this paper is in line with reality and can be used for modeling. As a whole, it can be seen that the green credit business plays a normal role in promoting the increase of the total asset income of commercial banks. This is consistent with the assumption in this paper.

As a whole, it can be seen that the green credit business plays a normal role in promoting the increase of the total asset income of commercial banks. This is consistent with the assumption in this paper.

\section{Suggestions on the Development of Commercial Banks}

\subsection{Strengthen macro-economic control and optimize the asset structure of commercial banks}

A good macroeconomic situation will also bring great benefits to the all-round development of commercial banks. In recent years, due to the improvement of people's living standards and the increasing demand for credit, the non-performing loan rate has increased. The state needs to increase support for the development of green credit business of commercial banks to ensure that the macroeconomic situation is conducive to the development of commercial banks. In addition, commercial banks need to know more about credit investigation, improve loan access mechanism, increase credit line to people with good credit, control the proportion of non-performing loans in advance, and optimize their asset structure.

\section{2 innovate its own business model and improve the competitive strength of commercial banks}

On the one hand, under various competitive situations, commercial banks should expand their business scope, strengthen the development of other types of business such as intermediary business, train high-quality professional staff, provide better service to customers, and help to improve the return rate of the broad audience. On the other hand, strengthening information construction, continuously improving work efficiency, expanding information disclosure, improving public awareness and goodwill, thus causing the linkage effect of deposit and loan and promoting the increase of yield. Commercial banks should strictly control their own service experience and seek common ground while reserving differences with other platforms. While developing themselves and improving their competitiveness, it is also necessary to better understand their social responsibilities and promote sustainable development.

\subsection{Strengthen market supervision and establish and perfect the supervision system}

At present, all kinds of platforms in the market are mixed up with good and evil people, which has worsened personal credit and market environment. Under various kinds of malicious competition, the development of banks has already encountered a bottleneck period. In this environment, survival and development have become difficult. The state should actively introduce various laws and policies to help commercial banks tide over the difficulties, encourage commercial banks to make efforts to break through, at the same time, crack down on such illegal institutions and improve the market environment. Financial institutions should also establish and perfect a green credit supervision system to monitor their own applications. Regulatory agencies such as the Bank Supervision Committee should also establish and improve the green credit evaluation standards for commercial banks, promote the transformation of bank loans, and promote the stable and sustainable development of ecological credit business.

\section{Conclusion}

In the theoretical analysis part, this paper expounds the basic concepts and related theories of green credit and profitability of commercial banks, and the development of green credit in China. Next, it expounds the theoretical analysis of the influence of green credit on the profitability of commercial banks in our country, and also lists the internal and external factors that affect the profitability of commercial banks, laying a theoretical foundation for the following empirical analysis.

In the empirical analysis part, this paper collects and sorts out the relevant financial indicators in the annual 
reports of the ten banks from 2009 to 2018, including Industrial and Commercial Bank of China, China Construction Bank, Bank of China, Agricultural Bank of China, Bank of Communications, CITIC Bank, Industrial Bank, Ping An Bank, China Minsheng Bank and China Merchants Bank, and then establishes a multiple linear regression model to confirm the positive correlation between green credit and profitability of commercial banks.

Finally, on the basis of regression analysis, aiming at the research conclusion, this paper puts forward some feasible suggestions for the development of commercial banks, such as optimizing asset structure, innovating business model, perfecting supervision system and innovating green credit products.

\section{References}

[1]Missbach,A.The Equator Principles:Drawing the line for socially responsible bank?An interim review from an NGO perspective[J].Development,2004,47(3):78-84.

[2]Scholtens,Bert and Lammertjan Dam.Are Banks that Adopted the Equator Principles Different from NonAdopters? [J].World Development.2207:1307-1328.

[3] Mathuva D M,Kiweu J M.Cooperative Social and Environmental Disclosure and Financial Performance of Savings and Credit Cooperatives in Kenya[J].Advances in Accounting,2016,35(9).

[4]Finger M, Gavious I.Manos R.Environmental Risk Management and Financial Performance in the Banking Industry :A Cross-country Comparison[J].Journal of International Financial Markets Institutions \& Money,2017,52(9).
[5]Dang Chunfang,Thoughts on Promoting Green Credit in China's Commercial Banks[J]. Modern Economic Research,2009,(2).

[6] Wang Xianju,How to Develop Green Credits of Commercial Banks in Low-carbon Economy[J].Reformation\&Strategy,2012(5):80-83.

[7] Liu Chuanyan,Inquiry into Developing Problems of China Green Credit [J].Taxation andEconomy,2012(1):29-32.

[8] $\mathrm{Hu}$ Naiwu,Cao Dawei,Green-Credit Policy and Environmental Risk Management of Commercial Banks[J].on Ecnomic Problems.2011(3):103-107.

[9]Chen Hairuo,Review and Prospect of Green Credit Research [J].Financial Theory\&Practice, 2010(8):9093.

[10] Shen Xiaohui,The Research on Green-credit,Green Reputation and Financial Performance of Commercial Banks[D].School of Finance Nanjing University of Finance and Economics,2012.

[10] Shen Xiaohui,The Research on Green-credit,Green Reputation and Financial Performance of Commercial Banks[D].School of Finance Nanjing University of Finance and Economics,2012.

[11]Li Cheng,Bai Wei,Wang Ye and Li Yushan,How can the green credit policy be effectively implemented by commercial banks? [J]. South China Finance, 2016(01):47-54.

[12]LI Yu,HU Haiya and LI Hao,Empirical Analysis of the Impact of Green Credit on the Upgrading of China's Industrial Structure: Based on Chinese Provincial Panel Data[J].on Economic Problems,2020(01):37-4. 